\title{
Afterword: Breath-Taking-Ethical Impulses for Breath Studies
}

\author{
Peter Adey
}

I seem to spend most of my academic life-perhaps it is embarrassing to say or write it-trying to find inspiration. What seems a kind of nourishment from a book, conversation, or conference paper that you feel before you know it. The feeling aspirates as I notice myself inhaling. It is bound up in the feeling of the chest cavity, my body and self lift and expand, and I try holding onto the feeling for as long as possible before it is exhaled in anticipation of the idea to be worked with later. Not lost.

This contribution grew out of the Life of Breath conference and from a collaboration with a 'feedback' team of early career scholars who spent time behind the scenes identifying themes and organising them with me into the form of discussant comments at the end of the conference. ${ }^{1}$ Working with and departing from those original thoughts, I want to play with the hook of this essay's title, 'breath-taking', as a way of signalling the extraordinary scope and depth of essays working with breath across a terrain of disciplines, temporalities, and indeed terrains or spatialities of physical landscapes, cities, clinics, interiorised and imaginative geographies

\section{P. Adey $(\bowtie)$}

Royal Holloway University of London, Egham, UK

(C) The Author(s) 2021

D. Fuller et al. (eds.), The Life of Breath in Literature, Culture and Medicine, Palgrave Studies in Literature, Science and Medicine, https://doi.org/10.1007/978-3-030-74443-4_25 
of literature. These set up more than a cross-disciplinary dialogue or the loose coordinates of endeavour: they offer possibilities of a germinal field, perhaps a 'breath studies', that sees numerous approaches, disciplines, and subject matters accord in quite remarkable ways that transcend, as Tsentourou suggests, more than locations, but rather represent a 'depth of transhistorical and transliterary points of reference'. For Craik and Chapman, the book provides the possibility of drawing on a reservoir-an ocean of air-breathy meanings, experiences, and concepts, and cultural and creative experiments in writing, to 'shed light on the conceptual categories which shape medical approaches to breathless patients now'. Such illuminations work in different directions through the collection, many of them aesthetic. As Wilton surveys different artistic practices and works she identifies the 'joint ownership' of a problem, where art and other cultural forms might 'mediate the gap' between different points of view.

In this way The Life of Breath is breathtaking. It arrests, sometimes in moments of distinct clarity, in crystal clear prose, but I think especially in the confusions and hesitations, confluences and incongruences that work between and across the diverse chapters. The Life of Breath is much more than its parts.

In the time and events that have passed since the conference, I want to invoke breathtaking in another critical and I hope affirmative way. This builds on a political and ethical conceit or inspiration at the heart of the volume, which has since become apparent in the momentum of current events - and which the editors have noticed so acutely in their introduction in relation to COVID-19-but also in the way the chapters attune to accounts of alterity, marginality, misogyny, gendered and sexual differences, environmental degradation, classed suspicions, and bodily violence. What might be added is that, today, breathlessness, breath inhibition, breath interruption and breath-taking seem the outcome of a convergence of problems for breath: a global pandemic in the form of the respiratory virus COVID-19, the struggle to breathe in the context of air pollution and climate change, waning environmental biodiversity and species-level extinctions, and the growing movement to oppose and reject police and state violence that has suffocated people of colour by the use of forceand many acknowledge the historical (re)production of these moments of violence involving asphyxiation. The slow and fast violences and vocalisations of breath are undoubtedly among the defining moments of our times. 
The overt political and contemporary taking of breath is clearly in accordance with the critique of anti-black tendencies and presences within institutions, police forces, and a wider atmosphere, or what Christina Sharpe has called the 'weather', of racism. ${ }^{2}$ Heine, turning directly to these energies in Nathaniel Mackey and M. NourbeSe Philip, accounts for the orientation to breath as a "returning "to the basics" in moments when everything becomes uncertain. [...] Breath, especially black breath, is as such "subject" to "precarity". While there is an overt absence of people of colour within this collection, and a general-although not exclusive-focus on traditions and contexts from the global north, the book and its attention to breath offer a clear and powerful, highly contextualised yet ethical impulse with which to tackle the precarity of breath more generally in uncertain times, both today and in the past, from the streets to the clinic, to the literary, spiritual, medical, and scientific imagination. I try to suggest how these breath(-)taking elaborations might therefore offer something of a critique, but not the death of hopeto paraphrase Lawlor's account of consumption in literature. What the moment demands, and what a focus on breath might nourish, are ethical sensibilities attuned, transhistorically and across disciplines, towards a generosity where breath is not taken but shared, co-produced, given. Such a generosity should be at the heart of what a Breath Studies tries to do.

\section{Conspiration AND Conspiracies}

In a recent article for the New Statesman the journalist and academic Gary Younge, like others, has drawn a parallel between COVID-19 and the public protests and expressions of anger levelled at racism and racial inequality. ${ }^{3}$ Younge follows the Public Health England report on Disparities in the risk and outcomes of COVID-19 which suggests that 'People of Chinese, Indian, Pakistani, Other Asian, Caribbean and Other Black ethnicity had between $10 \%$ and $50 \%$ higher risk of death when compared to White British'. ${ }^{4}$ Younge argues that there is some sort of 'connective tissue' between some of these conditions, between 'the most brazen forms of state violence and the more banal tribulations of the ailing pandemic patient'. As D. Asher Ghertner asks concerning the crisis of air pollution in India and premature mortalities due to air pollution, ${ }^{5}$ 'when the source of death is diffuse and leaky, literally shifting with the winds and gathering different compositional suspensions of matter', what happens to 'social culpability'?6 In short, a variety of commentators are noticing a manner 
of conspiration if not a conscious conspiracy, a tying together, a linking together through complex chains and feedback loops that define not just environmental systems, but the deep entanglements of global disease with localised air pollution levels, with global climate change, and movements for social change against systemic racism. As Bernini suggests, other feedback loops persist at more personal scales-breathing is understood as a physiological basis for consciousness. Breath feeds back into qualitative experience.

Sharpe has positioned the lack of breath, and indeed the earlier origins of the vocalisation 'I can't breathe', within what she calls the 'wake' of slavery, in the experiences of anti-blackness in the United States, signalling the suffocation of Eric Garner on Staten Island in 2014 by NYPD officers applying a 'choke hold' as a key case. Garner's death, and more recently George Floyd's, display a pattern of the suffocation of Black lives from the underbellies of ships of the Middle Passage onwards. What we are seeing is how powerful admixtures of air and breathlessness are coming together in the voice of protest and political force that Ashon T. Crawley has characterised as a 'disruption, an ethical plea'.

Others have connected the vulnerability of Black, Asian, and minority ethnic communities not only to COVID-19 but also to the suffocation of the Grenfell Tower fire victims, where the tower's residents were asphyxiated and poisoned by hydrogen cyanide and other gases from the PIR insulation and ACM cladding which covered the building. ${ }^{8}$ Grenfell has raised awareness of inadequately protected high-rise structures in Britain which are disproportionately occupied by people of colour. ${ }^{9}$ This was precisely the relationship Professor Leslie Thomas QC observed at the resumption of the Grenfell Tower inquiry in 2020. The resounding words of dying residents in calls made to emergency 999 telephone operators, echoing with the slogans of Black Lives Matter ('We can't breathe'), were projected onto the Grenfell Tower scaffolded façade-another way to make 'visible' marginalised and invisible lives in order to make them count. $^{10}$

\section{CAPACITIES}

The bodies in this book reveal breath's unusual role in stabilising fields of power and control, autonomy and automation, positioning subjects in unequal and hierarchical relations to one another, by their capacities to breathe and strike speech, and their relative life chances. As Hunt 
argues in his essay on late antiquity, 'breath is subsumed within the discourses of mastery and property ownership by which social and political relations were understood': breath orders social relationships, whether defined by ownership, by masculinity, or by mastery over property. Gray makes a similar point through his exposition of the relationship between the Monarchy, the Church, God, and the public within a sermon of John Donne on the limits of power, where breath signals both life and spirit. In one sense the King is our breath, our breath is his. Spirit not so. For Gray breath produces and reveals particular social orders, shaping capacities to rule and be ruled, to resist, protest, and speak out.

Walker and Rose debate contentions over breath and breathing within the arguments of psychoanalysis, and reveal a view of breath within the conscious and unconscious body, and a chance to think about breathing in relation to those actions involuntary to or autonomous from the conscious self. In part, these studies reveal the body's capacity to wield breath, to speak, and to navigate social and political hierarchies-how categories of social and bodily difference position bodies in different relations to breath and to the world. Who has breath, and who is short of it? Who breathes, and who doesn't?

The breaths that dominate this book are failing sorts of breath, struggling, volatile breaths. Coughing, sneezing, choking, sighing, swooning, gasping, crying, sobbing, an excitable kind of breathing, although we see in Renevey's essay a soothing, meditating kind of breath, and a recuperative one in Knoeff's. A fragile, grotesque breath definitely turns up in the consumptive in Lawlor's essay initially-the consumptive's expiration is a horror, 'malfunctioning, rotting, stinking, arhythmical, failing and dying', as the body is turned almost inside out, before it is re-taken as a calm, a feeble and feebler, melancholic breath. Both disable the body. And yet, while there are strong parallels in literature, for Skinner literary sensibilities normatively order capacities to act within constraining fields of social propriety and moral judgement. To this extent breathlessness does not simply signal 'incapacity' but, for Skinner, 'intense and instinctive moral discernment' as a 'vital condition for action'.

We might say then that The Life of Breath shows us that our capacities to act, to affect and be affected, are in constant negotiation, transformation, distribution, mutually reinforcing and reverberating through micropolitical relations that breath causes us to take seriously. Thus the body gains form as breath is registered on it, just as, for Saunders, the breathing body configured in the affective thought spaces of medieval 
literature was a porous one into or from which the spirits in the form of breath rushed or withdrew. In moments when breath becomes vulnerable so too does the body become light and light-headed, says Renevey; deformed, concurs Lawlor, tingly, heavy, even about to evaporate on death. For Bernini, it is impossible to separate thought from feeling, where breath takes on an agency and autonomy of its own in biocognitive feedback. For Saunders in Middle English secular romances, breath and consciousness are more an interweaving. In other words, breath complicates powers to act by distributing pneumatic agencies and forces once we recognise the incorporation of the body and the world, and their transformation. Breathing bodies are trans-incorporating. Hydrocarbons previously extracted from the air and buried in the ground are unearthed, released, and re-materialise in a form of sludgy, soupy thickness, while being absorbed differently, settling in our homes, perhaps as dust, in our lungs, and in our bloodstreams, in and on plants and animals which are suffocated. Spiritual and affecting forces and elements flood through our porous selves.

\section{INSCRIPTIONS}

Certainly the breath-taking explored in this volume sees breath not only inscribed, but inscribing, through measurement, recording, and distillation in language, speech and writing, and even the techniques of reproducing breaths in the manual practice of cutting audio tape-as the interview with Symmons Roberts mentions-where breath is registered as a gap. What happens to breath when it takes to the air, and when it is taken down again in other forms, even if what is taken down might be an absence, and could appear to be superfluous? Skinner demonstrates the role of the ellipsis in literature in the way that breathlessness is written, which in itself is an index of particular emotions and of high emotional stress and intense moral problems. For Lawlor, breathlessness is similarly etched in the punctuations of 'dashes, commas and semi-colons'. The dot dot dot of the ellipsis marks out other writings through which the essays demonstrate breath has been monitored and tracked, captured in its rhythms.

Others find an excess in the taking down of breath that offers possibilities for breath to be otherwise. For Knoeff, traditions of landscape depicting rural scenes were about a capturing of air: 'Through gazing at such paintings, the beholder would follow a visually cathartic process of 
purification', in moving from bad air into a purer environment, to the wholesome air in which the painting moved. Knoeff's chapter shows how air was held down, stored, and preserved, surviving within the picture frame of a Dutch landscape painting for recuperative and health-giving purposes. In another way Fuller discovers breath in the 'projective' poetry and associated prose of Charles Olson and in Paul Celan's post-Holocaust poetry and criticism. In Olson, breath could structure writing in such a way that one who reads it might 'hear Olson breathe', while in Celan, the emphasis is not on reading but on speaking: 'the reader must use not the eyes but the mouth', Fuller suggests, to find the meaning of 'living breath' in the poem's structure. Breath might be a pre-conscious form of voice, a kind of pre-verbal meaning, Symmons Roberts postulates. In this sense, The Life of Breath encourages us to look beyond breath's taking down as a kind of capture or remote abstraction-a paradox of capture and 'loss' that Fuller and Symmons Roberts contemplate even within the body's own memory. In its very abstraction we are offered therapeutic remedies and creative impulses that animate, that give life.

Wilton reminds us of Cornelia Parker's Breathless (2001), a permanent sculptural installation in the V\&A Museum (London), occupying the oculus space between two floors of the building. Fifty-four brass instruments have been crushed, pressed flat and arranged to radiate outwards. Parker explains that the instruments are about taking the wind out of the imperialism the institution signifies, a 'last gasp of empire': the instruments 'in my piece are permanently inhaled. They've literally had the wind taken out of them', Parker suggests. In Parker's and Wilton's wider practice, the works express a taking of breath which rejects the vestiges of colonialism through more positive and questioning inscriptions of breath that can be beautiful, such as the condensation marks from the breath of patients in Pulmonary Rehabilitation Unit I at the Royal Brompton Hospital on the surface of the copper that are etched into the material in Wilton's Breathe.

\section{(Dis)Placements}

As a geographer I am particularly drawn to the different spatialisations of breath at play in the volume, ${ }^{11}$ spaces which appear multiple and complex rather than singular. We might note that breath connects the clinic, the hospital, the vertiginous, the home, the city and its walls and gates, the church, the factory, and different surfacings and dimensions of space and 
breath down to, for Symmons Roberts, the meteorological conditions of a regional air that could be thicker, thinner or 'damp', shaping breath and the nasal intonation in voice. For Symmons Roberts, the body has a fleshy geography of breath, and not only in his fiction of a lung for transplant that leaves one body and crosses borders to go into another. Or for Russell, colonial circuits of trade mean breath-modulating, debilitating or stimulating substances like tobacco moving across the world, making the atmospheres of public space in the industrial city that bit denser, more social, and self-reflective, and, more widely, affecting the European arts, literature, and cognitive thought.

Despite Freud's misgivings about breath being too superficial an index, Walker and Rose see how climbing a mountain can reveal breathlessness as an expression of trauma. Corton and Rawcliffe show, with clarity and care, in the geographies of both Victorian London and the medieval city, how admixtures of pollutants and chemicals have been expelled into the skies, streets, and alleyways-Victorian atmospheric pollution; fly-tipping in the Middle Ages. Those spacings express, to some extent, class differences-depending on one's position in relation to the prevailing winds, although they too are contingent. These geographies were also imaginative: as Rawcliffe shows, the stench of medieval London meant the city could be compared with hell.

The book helps upset our assumptions about where breath might be problematic, when it becomes a problem, or comes to express multiple conflicts and violences. At the same time it flips some of our preconceptions of space, so that the home is not the refuge we might think in some of the cases of violence and misogyny shown in the essays. Such instances accord with what we are told about COVID-19's social spread in 'domestic settings', or the terrible but unsurprising rises in domestic violence reported by social care and health visitors during so-called 'lock-down'.

The spacings of breath show us where breath becomes harder, more problematic, more controlled. For Rawcliffe, medieval urban infrastructures re-routed animal carcasses and water courses, constructed new city passages and underground ways, and commenced street cleaning and disposal of other noxious waste so as not to pollute the urban breather. Other essays show how these barriers have been overcome by apparatus designed to help people occupy and breathe in different environments. Garrington's extraordinary essay explores the development and reception of apparatus for navigating and inhabiting the inhospitable spaces of the 
Alps or Himalayas. Here men highlight the difficulties of ascending to climates of thinner air, and the problems that breath-supported apparatus meant for a muscular masculinity when the face was obscured. As Garrington puts it, 'masks distanced the mountaineer as a human and from the mountain', with connotations of trench warfare, cowardly and faceless contestation, and anonymity. There are of course further parallels with the face-covering debate today in the time of COVID-19, that range from a political leadership - in some quarters - seeing the mask as a signal of defeat, to, by the mask's very absence, a leadership hiding from political and global problems. The breath mask or covering seems both divisive and to distance us from each other: it becomes antagonistic, it raises suspicions, and of course elsewhere it has long been a regular feature of life living with smog, air pollution, and pandemics. For survivors of domestic abuse, face masks can re-ignite past traumas through the experience of 'hot air, not being able to breathe freely, or feeling smothered', with inhibited mobility as a consequence, a possible continuation of abusive control which has restricted women's freedoms. ${ }^{12}$ With or without a mask then, there may be no space, no room to breathe.

Crawley has suggested that what goes 'unremarked is how breathing air is constitutive for flight, for movement, for performance', 13 noting how punishment has evoked dreadful shrieks and outpourings of breath through the violent displacement of flesh. But what of how breath constitutes movement? Crawley parallels the aestheticization of Black bodies with escape in the form of the fugitive slave, with the stigmatisation of the dancing Black body, moving apparently uncontrollably, whooping. While the examples in this book mainly stay with scenes of an intimate scale, of moving bodies at the level of the rise and fall of the chest, Heine reminds us that other movements and mobilities also matter.

Breath also expresses the social exclusions of normative spaces. Riddell's essay highlights particularly 'straight' heteronormative spaces such as the stifling setting of the bourgeois domestic home. But, he also shows, more affirmative and queer spaces are possible too. O'Gorman's essay associates the organ in the church with a kind of building by breath itself through the organ's heavenly exhalations, albeit at the Colston Hall in Bristol named after the philanthropist but also slave trader, Edward Colston. Rather than closing down, breath builds into being acoustic architectures suitable only for the heavens, that would 'take one's breath away', writes O'Gorman. In Riddell's account the precarity of straight spaces is not all-encompassing, and neither, conversely, are the organ's 
hands or the reliability of the machinery in O'Gorman's. For Riddell, 'breath also becomes a tool for a form of affirmation of queer desire', a more affirming 'respiratory sensuality' (Walker and Rose) perhaps, and a critique of the normative; just as for Garrington, breath became a point of connection between men as a brotherly bond, arm in arm, 'brothers in lung'. Indeed, in a moment of a sermon, in the inhalation and exhalation of a congregation, Crawley finds the possibilities of an aesthetic sociality that 'must be common and used by all, for vitality, for life'. ${ }^{14}$

\section{Conspirations AND COMMON}

At a recent Black Lives Matter demonstration in London, a young music student, Geovane Silva, explained to journalists that: 'Racism is racism, and that's what we have to fight. We have to be just one, human beings, we just need to be one. We all breathe the same air, we all bleed the same color'. ${ }^{15}$ Silva articulates a primary but intuitive sense that encompasses a much wider cultural understanding of breathing as an ethical injunction: the air is something we share via breath. In breathing together the same air through a sort of 'conspiration', explains Horky in crystal clear terms, we come to share something in common. ${ }^{16}$ It is by breathing together that feelings of sympathy, responsibility, and care may flourish. Breathperhaps through prayer, as Renevey and Symmons Roberts suggest-can be a kind of communication, a oneness with God in a kind of sovereign, vertical, yet intimate relation.

What is so strongly conveyed in The Life of Breath is how breath struggles so hard more horizontally, in multiple dimensions, to refuse the separations, enclosures, singularities, and exclusions of air that work on breath itself. Even the taking of breath becomes a loss that might be shared, as Heine shows in relation to M. NourbeSe Philip's Zong!: 'someone once breathed for us, gave her breath away; she might have been forced to do so, after her freedom and body were taken; at the outset, our breath was not our own, and probably it never is, never will be'. For Heine, the reformulation of Black exclusion and subjugation articulates a kind of possibility of commoning, of being in common that is founded on the sharing of a lack with others, continuing perhaps the suspicion of infinite breath O'Gorman considers. In other words, breathtaking might be a way to come together and accept difference. For Heine, Philip's suggested 'blueprint for community', the common memory of 'what it was to have someone breathe for us', implies recalling an 'act 
of acceptance of alterity'. Horky's 'conspiration' is for Heine a 'partage: sharing a lack'.

Throughout this book, the common and the commons treat breath as a shared resource. Breathing as one, in time, or asymmetrically, folds in other agents, maybe non-humans, and even animals. Rosalyn Diprose's notion of 'corporeal generosity' helps us to think this through. ${ }^{17}$ Breathing might presuppose, in a giving to the air and to each other without meaning to get anything back, a manner of openness. As Long shows, this relation may be ecological: 'Our life's dependence on breath and breathing puts us into a direct and intrinsic relationship with one of the planet's great powers along with water, solar heat, and light'. Breath helps us, in the terms we started with, commune with collapsing boundaries between bodies, but also scales, from the 'microcosm or individual person to the macrocosm or the world as such'. In a different vein, Tsentourou complicates this claim even further, to see conspiration, 'not only between bodies or between bodies and the cosmos, but also between bodies and texts'. Russell suggests that the imagination of the body as 'chronically unstable' and subject to transformation in traditional societies of the Amazon further nurtures an openness between 'human and non-human, animals, plants and objects'. A substance like tobacco can stimulate a recognition of positionality and a decentering of self in Enlightenment thought and culture.

Corton's essay reminds us that these conspirations include animals, who became the unwilling sufferers of London smog, and in recent times are the subjects of species-level extinctions in an era of climate crisis. Corton's explication moves from the blackening of the lungs of a lion at London zoo, to the clogging of plant stomata by soot, and the coating of evergreens with greasy deposits. In Knoeff's essay on breathscapes, the environment, even representations of landscape-while part of a concerted effort of 'taking the air'-are surely generous in their production of air for us to breathe. In this sense, breath connotes an ethical responsibility to each other and other things. And it was-or seemednot all bad in London's smog, for, as Long shows in classical thought, breath is often treated as a nutriment alongside food and drink, 'the prime nutriment'. As Corton concludes, London fog was not only the 'breath of death', although it could be a form of 'poison as well as a kind of nutrition in the popular and literary imagination'.

Finally, although the porosity of the body seems in one way to be sealed by the technologies shown in this book to help us breathe, or to 
filter air out in avoidance of pollutants or disease, we are given promise of a more than visual visage-covering to achieve openness. Walker and Rose give an account of psychoanalysis's study of a mother assuming the breathing pattern of a new-born baby. This was interpreted as a kind of hypnosis, a 'mimetic faculty' to the extent that breath and anxiety are not only co-productive, but that breathing together in respiratory response to the hearing of a breathing rhythm can be a way to generate empathy and sympathy. Craik and Chapman notice something similar in their translations and sympathies across literature and clinical medicine, suggesting that 'what it means to see, hear, and witness the breath (and breathlessness) of another' can carry what they call 'the weight of responsiveness and responsibility involved in all human relations'. Breath is a 'reciprocal or shared exchange'. Breathing together. Breath seems necessary for communion and community. Breathing in this book articulates feelings of affirmative exteriority, pushing oneself outside to become closer to others, to shared air, to blurred boundaries, from the skin's porosity to extra-bodily consciousness, as Renevey explores in relation to Holotropic Breathwork and yogic practices of breathing - an expansion of self via spiritual communion.

The Life of Breath offers the kind of affective, intellectual, critical, and ethical nutrition breath itself has been shown to promise throughout this volume. It sets up several critical incisions into the contextually specific, historico-geographical, and medico-legal, and into concerns of art and the imagination, whether for rule and governance in late antiquity, the medieval city, literature and romance, or clinical practice in the hospital today. It offers transdisciplinary and transhistorical possibilities that place apparently improbable associations, concepts, experiences, and beliefs almost side-by-side. In conspiracy, capacity, (dis)placement, inscription and conspirational commoning, across the essays are found forms of critique and diagnoses of power structures between institutions and people, and of normative conventions of sexuality or class. These modes of critique can reveal excesses offering possibilities of rupture and escape. At the heart of the book is an affirmative, commoning impulse, which conspires to see breath shared, even in its lack, across humans and non-humans. 


\section{Notes}

1. This included Fredrick Nyman, Kathleen Reynolds, Maryam Golafshani, and Natalie Goodison, and we were expertly organised with imagination and good humour by the facilitator Mary Robson.

2. In the Wake: On Blackness and Being (Durham, NC: Duke University Press, 2016).

3. Gary Younge, 'We Can't Breathe', New Statesman, 5 June 2020.

4. Public Health England, Disparities in the Risk and Outcomes of COVID19 (London, 2020), 6.

5. On these issues see Kamal Jyoti Maji, Mohit Arora, and Anil Kumar Dikshit, 'Premature Mortality Attributable to PM2.5 Exposure and Future Policy Roadmap for 'Airpocalypse' Affected Asian Megacities', Process Safety and Environmental Protection 118 (2018), 371-83.

6. D. Asher Ghertner, 'Airpocalypse: Distributions of Life amidst Delhi's Polluted Airs', Public Culture 32/1 (2020), 133-62.

7. Ashon T. Crawley, Blackpentecostal Breath: The Aesthetics of Possibility (New York: Fordham University Press, 2016), 1.

8. PA Media, 'Grenfell Relative Draws Comparisons between Fire and Covid-19 Response', The Guardian, 13 June 2020.

9. Danny Dorling, et al., 'Counting the $21^{\text {st }}$ Century Children of Britain: The Extent of Advantage and Disadvantage', Twenty-First Century Society $2 / 2$ (2007), 173-89.

10. Jane Macnaughton, 'Making Breath Visible: Reflections on Relations Between Bodies, Breath and World in the Critical Medical Humanities', Body \& Society 26/2 (2020), 30-54.

11. Sasha Engelmann, 'Toward a Poetics of Air: Sequencing and Surfacing Breath', Transactions of the Institute of British Geographers 40/3 (2015), $430-44$.

12. See https://www.womensaid.org.uk/covid-19-domestic-abuse-survivorsexperiencing-severe-distress-when-wearing-a-mask-are-exempt/.

13. Blackpentecostal Breath, 33.

14. Blackpentecostal Breath, 45.

15. Angela Dewan, “The UK Is Just as Bad as America": Londoners Mourn George Floyd and Demand Black Justice at Home', CNN World, 3 June 2020.

16. Luce Irigaray, The Forgetting of Air in Martin Heidegger, trans. by Mary Beth Mader, Athlone Contemporary European Thinkers (London: Athlone, 1999).

17. Corporeal Generosity: On Giving with Nietzsche, Merleau-Ponty, and Levinas, SUNY Series in Gender Theory (New York: State University of New York Press, 2002). 


\section{Selected Bibliography}

Crawley, Ashon T. 2016. Blackpentecostal Breath: The Aesthetics of Possibility. New York: Fordham University Press.

Diprose, Rosalyn. 2002. Corporeal Generosity: On Giving with Nietzsche, Merleau-Ponty, and Levinas. New York: State University of New York Press.

Engelmann, Sasha. 2015. Toward a Poetics of Air: Sequencing and Surfacing Breath. Transactions of the Institute of British Geographers 40/3: 430-44.

Irigaray, Luce. 1999. The Forgetting of Air in Martin Heidegger. Trans. by Mary Beth Mader. Athlone Contemporary European Thinkers. London: Athlone.

Macnaughton, Jane. 2020. Making Breath Visible: Reflections on Relations between Bodies, Breath and World in the Critical Medical Humanities. Body \& Society 26/2: 30-54.

Sharpe, Christina. 2016. In the Wake: On Blackness and Being. Durham, NC: Duke University Press.

Open Access This chapter is licensed under the terms of the Creative Commons Attribution 4.0 International License (http://creativecommons.org/licenses/ by $/ 4.0 /)$, which permits use, sharing, adaptation, distribution and reproduction in any medium or format, as long as you give appropriate credit to the original author(s) and the source, provide a link to the Creative Commons license and indicate if changes were made.

The images or other third party material in this chapter are included in the chapter's Creative Commons license, unless indicated otherwise in a credit line to the material. If material is not included in the chapter's Creative Commons license and your intended use is not permitted by statutory regulation or exceeds the permitted use, you will need to obtain permission directly from the copyright holder.

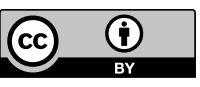

